\title{
METODE PEMBINAAN "BERDIKARI" UNTUK MENINGKATKAN KEMAMPUAN MENGAJAR GURU SDLBN KALIREJO TAHUN 2016
}

\author{
Sutras \\ Kepala SLB Negeri Kalirejo. Bojonegoro
}

\begin{abstract}
Abstrak
Penulisan ini bertujuan untuk 1) mengetahui peningkatan kemampuan guru mengajar di SDLBN Kalirejo, 2) mengetahui penguasaan kompetensi pendidik dan kompetensi professional, 3) membiasakan guru untuk "Berdikari" yaitu berlatih, berdiskusi, dan berkarya inovasi dalam pembelajaran. Penulisan ini dilakukan dalam dua siklus, setiap siklus ada empat kegiatan yaitu; 1) perencanaan, 2) tindakan, 3) Observasi, 4) Refleksi. Data yang dikumpulkan dengan menggunakan metode angket, wawancara terstruktur, dan tes. Metode angket digunakan untuk mengukur kemampuan guru dalam melakukan program pembelajaran. Wawancara digunakan untuk menggali faktor penyebab rendah dan tingginya kemampuan guru dalam pembelajaran. Tes diberikan untuk mengukur pengetahuan guru dalam menguasai ilmu pembelajaran. Berdasarkan hasil analisis, disimpulkan bahwa penerapan pembinaan dengan metode "Berdikari" dapat meningkatkan kemampuan guru mengajar dilihat dari adanya peningkatan persentasi, peningkatannya dapat dilihat dari hasil observasi pada siklus I dan siklus II. Pada aspek mendengarkan penjelasan pada siklus I persentasenya sebesar $70 \%$ dan siklus II sebesar $86 \%$. Aspek mencatat penjelasan pada siklus 1 sebesar 56\% dan siklus II sebesar $100 \%$. Aspek memperhatikan pembelajaran pada siklus I sebesar 54\%.dan siklus II sebesar $86 \%$. Aspek bertanya siklus I sebesar $28 \%$ dan pada siklus II sebesar $86 \%$. Aspek menjawab pertanyaan pada siklus I sebesar $28 \%$ dan siklus II sebesar $86 \%$. Aspek mengeluarkan pendapat siklus I sebesar $28 \%$ dan pada siklus II sebesar $72 \%$. Aspek menghargai pendapat teman pada siklus I sebesar $84 \%$ dan pada siklus II sebesar 86 $\%$. Aspek mampu menjelaskan kembali pada siklus I sebesar $45 \%$ dan pada siklus II sebesar 72\%. Pembinaan guru dengan metode "Berdikari" dapat meningkatkan kemampuan guru dalam memahami pengetahuan pembelajaran. Peningkatan hasil belajar ini dapat dilihat dari adanya perubahan nilai rata-rata yang diperoleh guru pada setiap akhir siklus. Nilai rata-rata yang diperoleh guru pada siklus I sebesar 50 dan siklus II sebesar 78,5.
\end{abstract}

Kata kunci : Metode Berdikari, Kompetensi guru.

\section{PENDAHULUAN}

Keberhasilan proses pembelajaran di sekolah menjadi tanggungjawab guru. Kemampuan guru dalam mengajar sangat berpengaruh terhadap peningkatan kenyamanan dan pemahaman peserta didik. Pembelajaran yang yang tidak didasari dengan pemahaman 
karakteristik guru, kemampuan, dan kebutuhan peserta didik, strategi/metode yang tepat, pendekatan pembelajaran yang tepat, didukung sarana dan prasarana pembelajaran yang memadai, dan motivasi serta ketulusan guru dalam mengajar, maka akan sulit mewujudkan pembelajaran yang nyaman, menyenangkan, dan mendapatkan hasil belajar yang maksimal.

Idealnya semua faktor pendukung keberhasilan pembelajaran harus terlaksana secara baik dan benar sehingga hasil proses pendidikan benar-benar dapat dirasakan oleh peserta didik, masyarakat dan untuk kemajuan bangsa. Penulis sadar bahwa SDLB Negeri Kalirejo belum sepenuhnya memenuhi delapan standar pendidikan, namun pelaksanaan standar pendidikan harus dirintis tahap demi tahap. Dalam hal ini standar pendidik dan tenaga kependidikan di SDLB negeri Kalirejo belum memenuhi standar kualifikasi akademik. Jumlah guru ada 6 dan tenaga administrasi 1 orang. Dari 6 guru terdiri atas 3 guru dengan kualifikasi S1 tidak linier dan 2 guru berpendidikan D2 dan 1 guru berpendidikan SMA. Dari enam guru ada dua guru yang berkebutuhan khusus yaitu tuna netra dan sakit kejiwaan, sehingga kurang produktif dalam mengajar, dua guru sarjana PPKn, seorang guru lulusan diploma dua agama Islam, dan seorang lulusan SMA namun masih menempuh kuliah S1 pendidikan olahraga.

Pada kesempatan ini penulis berfokus pada peningkatan kemampuan guru dalam mengajar yang disesuaikan dengan karakteristik, kemampuan dan kebutuhan peserta didik. Karena pada sisi ini kemampuan guru-guru di SDLB Negeri Kalirejo sangat lemah mulai dari kualifikasi akademiknya, tambahan keilmuan melalui diklat, seminar, workshop dan kegiatan pendalaman kelimuan tentang anak berkebutuhan khusus yang lain.

Karena minimnya bekal keilmuan guru tentang anak berkebutuhan khusus sangat berpengaruh pada kemauan serta kemampuan guru dalam mengajar. Yang terjadi guru mengajar tanpa persiapan seperti tidak adanya RPP, resum materi, silabus, peraga, dan perangkat pembelajaran yang lain. Guru hanya memenuhi jam kehadiran dan mengajar secara brainstorming (apa yang teringat waktu mengajar). Yang terjadi pembelajaran secara monoton dengan metode ceramah, guru yang aktif, dan berlangsung tidak menarik perhatian siswa.

Berdasarkan latar belakang permasalahan yang terjadi di SDLB Negeri Kalirejo maka penulis melakukan pembinaan dengan metode "Berdikari" untuk meningkatkan kemampuan guru mengajar di SDLB Negeri Kalirejo. Berdikari berasal dari kata berlatih, diskusi, dan karya inovatif. Dengan berdikari guru akan aktif berlatih mengajar yang baik, membuat RPP, silabus, penerapan pendekatan pembelajaran, penggunaan alat peraga, cara mengajar yang baik, serta melakukan penilaian pembelajaran yang autentik. Berdikskusi, dilakukan secara rutin di sekolah bersama dengan kepala sekolah dan seluruh guru dengan tema-tema yang mereka 
belum paham. Pemecahan masalah dilakukan melalui diskusi dan merujuk dari beberapa buku referensi. Karya inovatif, merupakan kelanjutan dari kegiatan pelatihan dan berdiskusi. Karya inovatif yang dihasilkan dapat berupa karya seni, alat pembelajaran, alat peraga, modul, karya ilmiah (PTK), dan makalah. Dengan kegiatan "Berdikari” harapannya mampu meningkatkan kemampuan guru dalam pembelajaran.

\section{KAJIAN PUSTAKA}

\section{A. Deskripsi Teori}

\section{Metode Berdikari}

Metode "Berdikari” kependekan dari kata berlatih, diskusi, dan karya inovatif. Berdikari yang merupakan gabungan dari tiga metode akan lebih jelas efektifitasnya dalam penjelasan berikut.

\section{a. Pengertian Pelatihan}

Pelatihan adalah segala bentuk kegiatan guru di luar jam mengajar yang bertujuan untuk dapat meningkatkan kemampuan profesionalisme guru dalam pembelajaran. Pelatihan dapat dilakukan dalam bentuk workshop, Pendidikan dan pelatihan (Diklat), seminar, lokarya dan bentuk lain.

\section{b. Diskusi}

Diskusi adalah bentuk kerjasama kelompok dalam menyelesaikan suatu permasalahan, dalam hal ini permasalahan pembelajaran yang sehari-hari dialami oleh guru. Diskusi bisa dilakukan di dalam sekolah maupun diluar sekolah tergantung masalah yang dihadapi. Diskusi dapat dilakukan secara terstruktur maupun tidak terstruktur tetapi harus ada pokok permasalahan, cara penyelesaian, referensi, dan pendapat dari peserta diskusi. Diskusi menghasilkan solusi yang dapat diterima bersama terkait permasalahan yang dihadapi.

\section{c. Karya Inovatif}

Karya inovatif adalah hasil kerja guru dalam rangka untuk meningkatkan kualitas pembelajaran. Karya inovatif dapat berupa rangkuman materi, makalah, puisi, sajak, karya seni, pembelajaran, alat peraga, modul, karya ilmiah, praktek terbaik (best practice), dan karya yang lain.

Dalam mengajar guru harus inovatif, apalagi dalam pembelajaran untuk anak berkebutuhan khusus lebih membutuhkan kemampuan yang variatif dan inovatif. Dari sisi konstruk materi untuk pembelajaran di SDLB memang rendah, tetapi karena kondisi anak yang mengalami hambatan sehingga walaupun konstruk kurikulumnya 
rendah membutuhkan berbagai cara/metode mengajar yang kreatif dan inovatif. Sehingga peserta didik benar-benar mampu menerima, mengerti, memahami, dan mempraktekkan materi yang disampaikan oleh guru.

Berbagai inovasi pembelajaran sangat penting dimiliki oleh guru pendidikan khusus dan harus selalu terbarukan. Pembelajaran yang penuh inovasi dicirikan dengan sesuatu tidak lazim dilakukan sehari-hari namun mampu memikat peserta didik sehingga pembelajaran menjadi hidup dan ada umpan balik dari peserta didik secara positif. Keaktifan, kegembiraan, dan kemajuan kemampuan siswa dalam menyerap materi yang disampaikan guru ini sebagai salah satu hasil keberhasilan guru berinovasi dalam pembelajaran.

\section{Kemampuan Mengajar}

\section{a. Pengertian Kemampuan}

Kemampuan berbeda dengan kompetensi, menurut penulis definisi kemampuan adalah potensi diri seseorang yang sudah melekat dalam dirinya, sangat mudah untuk dikembangkan, dan dapat diterapkan dengan penuh tanggungjawab dalam mengemban tugasnya. Sedangkan definisi kompetensi berdasarkan Undang-undang nomor 20 Tahun 2003 tentang Sistem Pendidikan Nasional, kompetensi adalah seperangkat pengetahuan, kemampuan dan perilaku yang harus dimiliki, dihayati, dan dikuasai oleh guru atau dosen dalam menjalankan tugas keprofesionalan.

\section{B. Kerangka Pikir}

Pembelajaran di sekolah menjadi tanggung jawab guru, sesuai tugas pokok dan fungsi guru yaitu mendidik, mengajar, membimbing, melatih, mengarahkan, menilai, dan mengevaluasi pekerjaan siswa. Guru membimbing serta mengajarkan ranah pengetahuan, sikap, dan keterampilan. Sehingga keberhasilan pendidikan di sekolah sangat bergantung pada keaktifan dan kreativitas guru. Guru yang kreatif akan menjadi sumber inspirasi siswa serta panutan yang tidak terlupakan. Siswa akan mudah mengenali dirinya dan mengembangkan kemampuannya jika dibimbing oleh guru yang mempunyai kemampuan yang tinggi serta inspiratif.

Secara umum pembelajaran oleh guru pada anak berkebutuhan khusus di SDLB Negeri Kalirejo kurang variatif. Cara penyampaian teori masih menggunakan metode ceramah dan mencatat. Tentunya pemahaman guru tentang materi yang disampaikan masih 
dirasa kurang. Hal tersebut dapat mengakibatkan partisipasi guru rendah sehingga akan mengakibatkan kemampuan belajarnya menjadi rendah. Oleh karena itu diperlukan inovasi lain yang dapat menarik perhatian guru untuk meningkatkan kompetensi.

Pembinaan dengan metode "Berdikari" akan menjadi tradisi positif bagi guru untuk meningkatkan kemampuan mengajar pada guru berkebutuhan khusus. Sehingga guru akan lebih memahami masalah yang ada pada dirinya sendiri, pekerjaan, dan masalah secara umum yang harus dipecahkan. Pembinaan metode "Berdikari" akan memperkuat memori guru dalam menguasai pengetahuan dan keilmuan melalui kegiatan diskusi sesama guru yang dipandu kepala sekolah. Dengan diskusi maka semua guru lebih terasah daya pikirnya, terbuka pemikirannya, dan akan berbuat lebih bijak dalam menyikapi segala permasalahan. Dengan demikian, penggunaan metode "Berdikari" pada proses pembinaan guru dapat memacu guru meningkatkan kemampuan mengajar dan lebih professional.

Supaya lebih dapat memahami pentingnya pembinaan dengan metode "Berdikari" dapat dilihat pada kerangka berpikir berikut;

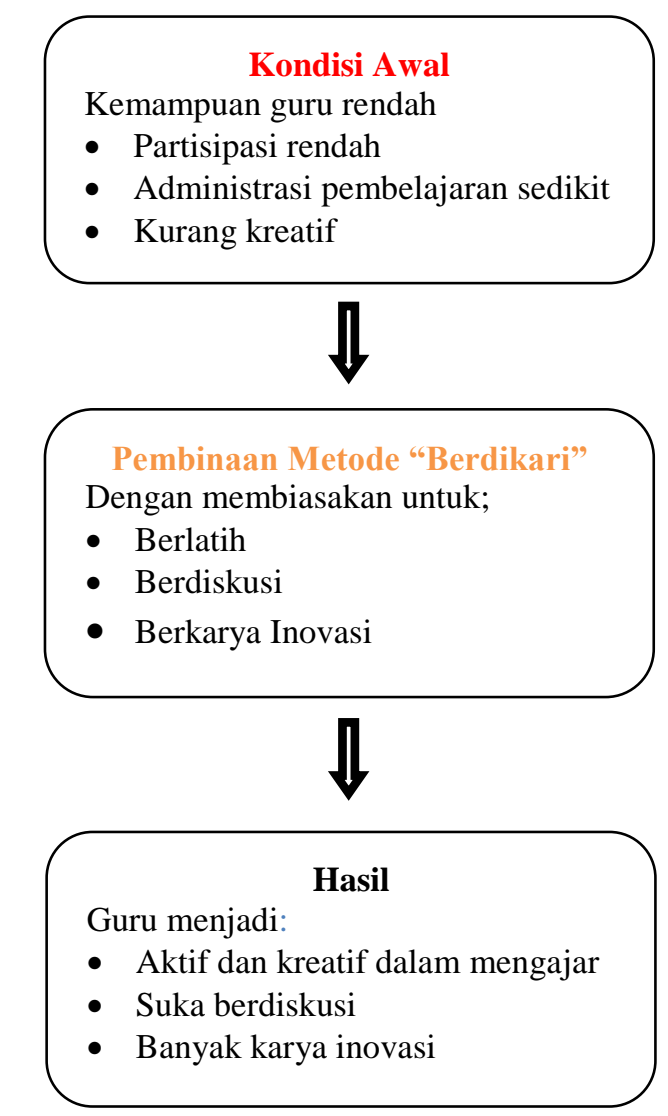

\section{METODE PENULISAN}

\section{A. Pendekatan dan Jenis Penulisan}

Penulisan ini dilakukan oleh kepala sekolah pada satuan pendidikan sehingga lazim disebut penulisan tindakan sekolah, yaitu mencermati proses kegiatan belajar mengajar 
yang berlangsung di sekolah yang dilakukan oleh para guru. Penulisan ini dilakukan secara partisipati bersama-sama dengan guru. Dalam penulisan tindakan Sekolah ini, guru bertindak sebagai pelaksana tindakan sedangkan penulis bertindak sebagai kolaborator.

Penulisan tindakan sekolah ini dilakukan oleh penulis, setelah melakukan pemantauan, diskusi, pengamatan, evaluasi, dan refleksi. Hasil evaluasi dan refleksi semua guru sehingga diputuskan pentingnya pembinaan 'Berdikari' untuk meningkatkan kemampuan guru dalam mengajar.

Dalam penulisan tindakan ini mencoba menerapkan variasi model pembinaan yang baru yaitu pada model pembinaan menggunakan metode 'Berdikari' yang diharapkan dapat memberikan perubahan ke arah perbaikan pada suatu proses pembelajaran.

\section{B. Subjek Penulisan}

Subyek dalam penulisan ini adalah semua guru kelas di SDLBN Kalirejo, Kecamatan Ngraho, Kabupaten Bojonegoro.

\section{Lokasi dan Waktu Penulisan}

Penulisan ini dilaksanakan di SDLB Negeri Kalirejo, kecamatan Ngraho kabupaten Bojonegoro pada bulan Oktober sampai Desember tahun 2016.

\section{Teknik Pengumpulan Data}

Pengumpulan data dilakukan dengan:

\section{Observasi}

Menurut Sutrisno Hadi dalam Sugiyono (2008), Observasi merupakan suatu proses yang kompleks, suatu proses yang tersusun dari pelbagai proses biologis dan psikologis. Dua diantara yang penting adalah proses ingatan dan pengamatan.

Pada penulisan ini penulis melakukan pengamatan langsung terhadap kegiatan yang dilakukan guru. Selain pengamatan perilaku, penulis juga mengamati bendabenda seperti buku, alat peraga, alat pendidikan, poster, jadwal pelajaran, media, serta benda apa saja yang menjadi penunjang pembelajaran. Observasi juga melibatkan guru sebagai subyek yang diamati (partisipan). Teknik ini digunakan untuk memperoleh data tentang situasi pembelajaran yang terjadi selama melakukan proses pembelajaran di kelas. Kegiatan observasi ini dilakukan disetiap pertemuan. Pengumpulan data dilakukan dengan instrumen lembar pengamatan.

\section{Wawancara}

Wawancara dapat didefinisikan sebagai "Interaksi bahasa yang berlangsung antara dua orang dalam situasi saling berhadapan salah seorang, yaitu yang melakukan 
wawancara meminta informasi atau ungkapan kepada orang yang diteliti berputar di sekitar pendapat dan keyakinannya" Hasan (1963) dalam Emsir 2010: 50).

Menurut Sugiyono (2008: 137) wawancara digunakan sebagai teknik pengumpulan data apabila penulis ingin melakukan studi pendahuluan untuk menemukan permasalahan yang harus diteliti, dan juga apabila penulis ingin mengetahui hal-hal dari responden yang lebih mendalam dan jumlah respondennya sedikit/kecil.

Menurut penulis, wawancara adalah alat untuk mengumpulkan informasi berupa sejumlah pertanyaan secara lisan kepada orang-orang yang dianggap dapat memberikan informasi atau penjelasan mengenai hal-hal yang dianggap perlu. Dalam hal ini wawancara dilakukan pada guru SDLB Negeri Kalirejo.

\section{Tes}

Tes digunakan untuk mengukur besaran kemampuan obyek yang diteliti. Menurut Suharsimi (2002:198) Tes prestasi belanjar yang digunakan di sekolah dapat dibedakan menjadi dua, yaitu (1) tes buatan guru dan (2) tes terstandar. Dalam penelitian ini tes digunakan untuk mengukur peningkatan kemampuan guru setelah mengikuti pembinaan dengan metode "Berdikari"

\section{Dokumen}

Menurut Sugiyono (2008: 240) dokumen merupakan catatan peristiwa yang sudah berlalu. Dokumen bisa berbentuk tulisan, gambar, atau karya-karya monumental dari seseorang. Dalam kegiatan ini dokumen yang dimiliki oleh guru-guru SDLB Negeri Kalirejo berupa foto, hasil kerja, portofolio, dan karya inovatif sebagai dampak setelah mengikuti program "Berdikari".

\section{E. Prosedur Penulisan}

Sebelum mengadakan penulisan, penulis terlebih dahulu melakukan pemantauan. Dalam kegiatan ini penulis melakukan pemantauan terhadap kebiasaan guru sebelum melakukan pembelajaran, perlengkapan pembelajaran, alat pendidikan, dan alat peraga. Penulis juga melakukan wawancara sekitar persiapan guru serta pengetahuan guru tentang karakteristik muridnya. Selanjutnya penulis mengadakan observasi terhadap situasi awal di dalam sekolah yang mencakup observasi kegiatan guru, observasi sekolah, dan observasi terhadap guru.

Penulisan ini dilakukan dalam bentuk siklus, masing-masing siklus terdiri dari perencanaan, tindakan, pengamatan, dan refleksi. Penulisan ini didesain sebagai Penulisan 
Tindakan Sekolah (PTS) yang akan dilakukan dengan beberapa siklus. Adapun langkahlangkah setiap siklus adalah sebagai berikut:

\section{Perencanaan}

Pada siklus pertama diawali dengan membuat perencanaan tentang materi dan pelaksanaan tindakan berupa penyiapan pembelajaran menggunakan metode "Berdikari" yang akan dilakukan di Sekolah. Penulis menyusun perencanaan pembinaan yang akan diberikan kepada para guru. Langkah-langkah yang dilakukan dalam perencanaan tindakan antara lain sebagai berikut :

a. Membuat RPP dengan materi yang diajarkan.

b. Menyiapkan metode "berdikari"

c. Menyusun lembar kerja guru.

d. Menyiapkan instrumen yang diperlukan dalam pembelajaran yang akan dilakukan.

e. Menyusun soal evaluasi.

\section{Tindakan}

Tindakan yang dilakukan penulis yaitu memberi pelatihan kepada guru tentang materi administrasi pembelajaran yang harus dibuat oleh guru seperti struktur kurikulum, jadwal pelajaran, program tahunan, program semester, silabus, RPP, program evaluasi, program remedial, dan program pengayaan. Selanjutnya guru diberi kesempatan untuk berdiskusi dan mempresentasikan hasil kerja.

\section{Monitoring Tindakan}

Berbekal adminintrasi pembelajaran yang sudah dibuat dan sudah dikonsultasikan dengan kepala sekolah selanjutnya guru menerapkan dalam pembelajaran. Pada saat proses pembelajaran penulis melakukan pengamatan serta melakukan penilaian. Hasil penilaian dijadikan bahan untuk melakukan evaluasi, memberi saran, dan bahan refleksi para guru.

\section{Refleksi}

Dalam tahap ini, penulis bersama kolaborator (guru standar kompetensi menangani penggandaan dokumen) melakukan analisis dan memaknai hasil tindakan siklus 1. Apabila dalam hasil refleksi terdapat aspek-aspek yang belum dicapai/ berhasil, maka akan dilakukan perbaikan pada siklus II. Pelaksanaan siklus II akan dilaksanakan setelah refleksi pada siklus I. Apabila di dalam siklus tersebut belum 
memenuhi kriteria yang ingin dicapai maka dilakukan siklus selanjutnya untuk memperbaiki kriteria yang sudah ditentukan.

\section{F. Teknik Analisa Data}

Dalam penulisan ini data yang ada dianalisis dengan statistik deskriptif, menurut Sugiyono (2008: 147) statistik deskriptif adalah statistic yang digunakan untuk menganalisis data dengan cara mendeskripsikan atau menggambarkan data yang telah terkumpul sebagaimana adanya tanpa bermaksud membuat kesimpulan yang berlaku untuk umum.

Analisis data yang digunakan dalam penulisan ini dilakukan terus menerus selama pengumpulan data berlangsung sampai pada akhir penulisan atau penarikan kesimpulan. Penulis merefleksi hasil observasi terhadap proses pembelajaran yang dilaksanakan guru di dalam Sekolah. Adapun yang dianalisis, sebagai berikut:

\section{Partisipasi aktif guru}

Untuk mengetahui apakah metode "Berdikari" dapat membuat guru lebih aktif dalam mengajar di kelas, data yang digunakan terdapat pada lembar observasi yang kemudian dianalisis secara deskriptif. Penilaian dapat dilihat dari hasil skor pada lembar observasi yang digunakan. Data observasi yang telah diperoleh, dihitung, kemudian dipersentasekan. Sehingga dapat diketahui seberapa besar peningkatan kemampuan guru dalam pembelajaran. Kriteria menghitung persentase peningkatan kemampuan guru berdasarkan lembar observasi adalah sebagai berikut :

Tabel 2. Kriteria Aktivitas Individu

\begin{tabular}{|c|c|}
\hline Persentase & Kriteria aktivitas guru \\
\hline $81 \%-100 \%$ & Sangat tinggi \\
\hline $61 \%-80 \%$ & Tinggi \\
\hline $41 \%-60 \%$ & Sedang \\
\hline $21 \%-40 \%$ & Rendah \\
\hline $0 \%-20 \%$ & Sangat rendah \\
\hline
\end{tabular}

(Riduwan, 2009: 15) 
Cara menghitung persentase aktivitas guru berdasarkan lembar observasi untuk tiap pertemuan adalah sebagai berikut :

$$
\text { Persentase }=\frac{\sum \text { Guru yang berpartisipasi }}{\sum \text { Guru keseluruhan }} \times 100 \%
$$

(Martinus, 2015: 49)

Dalam penulisan ini indikator yang dicapai bisa dilihat dari pencapaian poinpoin yang tertera dalam partisipasi belajar guru. Adapun poin-poin yang diamati untuk mengukur peningkatan partisipasi antara lain:
a. Mendengar Penjelasan
b. Mencatat Penjelasan
c. Memperhatikan pembelajaran
d. Bertanya
e. Menjawab Pertanyaan
f. Mengeluarkan Pendapat
g. Menghargai Pendapat teman
h. Mampu Menjelaskan Kembali

\section{Kemampuan Mengajar Guru}

Untuk mengetahui peningkatan kemampuan mengajar guru, penulis menggunakan butir kompetensi pendidik dan kompetensi profesional. Bila guru telah mencapai nilai sama atau lebih besar dari 7,5 dengan prosedur rentang nilai 0-10, maka dapat dikatakan memenuhi pofesional. Tetapi apabila guru mendapatkan nilai kurang dari 7,5 dikatakan masih belum profesional.

\section{HASIL PENULISAN}

\section{A. Hasil Penulisan}

\section{Kondisi Awal dan Perencanaan}

Sebelum penulisan tindakan dilaksanakan terlebih dahulu dilakukan pengamatan awal, agar mengetahui kondisi awal dan permasalahan pembelajaran yang ada di Sekolah. Dengan kata lain, adanya permasalahan di Sekolah itu yang nantinya akan menjadi fokus penulisan. Dari hasil supervisi yang dilakukan oleh penulis, kemampuan mengajar guru kelas di SDLBN Kalirejo dikatakan rendah karena masih 
ada guru memperoleh skor rendah dalam pembuatan RPP. Hal ini disebabkan guru masih kurang membaca, menganalisa, mendiskusikan, dan memahami masing-masing komponen RPP sehingga guru berpengaruh pada proses pembelajaran di kelas. Hal ini apabila tidak ditindaklanjuti tentu akan mengakibatkan proses pembelajaran tidak optimal dan mempengaruhi kemampuan belajar.

Melihat kondisi Sekolah yang demikian, maka agar permasalahan ketidakaktifan guru dalam proses belajar mengajar dapat segera teratasi, perlu dilakukan rekonstruksi terhadap media pembelajaran yang kurang melibatkan partisipasi aktif guru. Salah satu media yang bisa dijadikan sebagai alternatif untuk meningkatkan partisipasi aktif guru dalam proses pembelajaran adalah metode "Berdikari".

Agar mempermudah dalam pelaksanaan tindakan maka perlu dibuat suatu perencanaan. Perencanaan yang dibuat meliputi: menyiapkan materi peningkatan kompetensi guru dan buku penunjang pembelajaran, panduan membuat RPP yang baik dan benar, membuat RPP sesuai komponen yang ditetapkan kemdikbud. Melakukan diskusi dengan sesama guru dalam pembuatan RPP, dan pembuatan alat peraga serta media pembelajaran.

Melalui perencanaan sebelum melakukan tindakan akan diskusi sesama teman yang akan mempermudah dalam menentukan keberhasilan tindakan yang dilaksanakan. Perencanaan dapat dijadikan panduan pelaksanaan tindakan, sehingga penulisan yang dilakukan tidak jauh melenceng dari tujuan penulisan untuk menerapkan sebuah metode "Berdikari" dalam rangka meningkatkan kompetensi dan kemampuan guru.

\section{Hasil Tindakan}

\section{a. Siklus 1}

\section{1) Perencanaan Tindakan}

Perencanaan tindakan yang dilakukan pada siklus 1 adalah sebagai berikut:

a) Menyiapkan pembinaan metode "Berdikari"

b) Membuat Rencana Pelaksanaan Pembelajaran (RPP) tentang materi yang akan diajarkan. Rencana Pelaksanaan Pembelajaran ini disusun sebagai pedoman penulis dalam melaksanakan kegiatan pembelajaran di dalam sekolah.

c) Menyusun dan mempersiapkan lembar observasi untuk mengetahui partisipasi guru selama proses pembelajaran berlangsung. Lembar observasi ini digunakan sebagai pedoman penulis di dalam mengamati guru 
di sekolah. Lembar ini akan diisi pada setiap pertemuan dan dibuat oleh penulis.

d) Menyusun dan mempersiapkan instrumen yang digunakan untukmengukur kemampuan guru setelah proses pembinaan metode "Berdikari" berlangsung.

e) Mempersiapkan alat dan media yang akan digunakan untuk proses pembinaan metode "Berdikari" di sekolah.

\section{2) Pelaksanaan Tindakan}

\section{a. Pertemuan ke-1}

Langkah - langkah pelaksanaan tindakan pada siklus 1 pertemuan ke-1 adalah sebagai berikut:

(1) Kegiatan awal

(a) Penulis memberi motivasi terkait TUPOKSI

(b) Penulis mengecek administrasi yang sudah dibuat guru.

(c) Penulis memberikan apersepsi yang berhubungan dengan materi yang akan disampaikan

(d) Penulis memberikan motivasi kepada guru dengan memberi pertanyaan kepada guru

(e) Penulis menyampaikan tujuan pembinaan dengan metode "Berdikari"

(2) Kegiatan inti

(3) Penutup

(a) Guru menyimpulkan materi yang telah disampaikan.

(b) Penulis memberikan tugas rumah

(c) Penulis menutup kegiatan pelatihan dengan berdo'a

(d) Penulis mengucapkan salam.

\section{b. Pertemuan ke-2}

Langkah - langkah pelaksanaan tindakan pada siklus 1 pertemuan ke-2 adalah sebagai berikut:

(1) Kegiatan awal

(a) Penulis memberi motivasi terkait TUPOKSI.

(b) Penulis mengecek administrasi yang sudah dibuat guru pada pertemuan pertama. 
(c) Penulis memberikan apersepsi yang berhubungan dengan materi yang akan disampaikan.

(d) Penulis memberikan motivasi kepada guru dengan memberi pertanyaan kepada guru.

(e) Penulis menyampaikan pentingnya melakukan diskusi sesama guru dan berinovasi.

(2) Kegiatan inti

(3) Penutup

(a) Guru menyimpulkan materi yang telah disampaikan.

(b) Penulis memberikan tugas rumah.

(c) Penulis menutup kegiatan pembelajaran dengan berdoa.

(d) Penulis mengucapkan salam.

\section{3) Hasil Observasi dan Pembahasan}

Selama kegiatan pembinaan dengan metode "Berdikari" berlangsung penulis juga melakukan pengamatan secara langsung mengenai partisipasi yang ditunjukkan oleh guru dalam berkegiatan. Dalam penulisan ini, unsur-unsur yang termasuk dalam partisipasi guru atau keaktifan guru meliputi keaktifan guru, konsentrasi guru, mencatat penjelasan penulis, memperhatikan paparan, bertanya, menjawab pertanyaan, mengeluarkan pendapat, menghargai pendapat teman, refleksi/menjelaskan kembali.

Hasil kegiatan ini diketahui bahwa guru yang mendengarkan penjelasan sebanyak $70 \%$, mencatat penjelasan $56 \%$, memperhatikan paparan $70 \%$, bertanya $28 \%$, menjawab pertanyaan $28 \%$, mengeluarkan pendapat $28 \%$, menghargai pendapat teman $84 \%$, mampu menjelaskan kembali $45 \%$.

\section{4) Hasil Tes}

Hasil analisis tes ini diperoleh data berupa angka-angka mengenai jumlah nilai yang diperoleh masing-masing guru terhadap soal yang dikerjakan setelah menerapkan pembinaan dengan metode "Berdikari". Data yang diperoleh melalui tes dihitung jumlah nilai yang diperoleh masing-masing guru dengan cara mengakumulasikan masing-masing nilai pada setiap item soal yang dijawab guru.

Dalam menghitung nilai rata-rata guru secara keseluruhan digunakan rumus yang dikembangkan oleh Suharsimi Arikunto dalam bukunya Dasardasar evaluasi Pendidikan (2009: 264): 


$$
X=\frac{\sum}{N}
$$

Berdasarkan rata-rata guru pada post test 1 dapat diketahui sebesar 50 . Hal ini menunjukkan bahwa terjadi peningkatan hasil belajar guru setelah menggunakan metode "Berdikari”. Namun berdasarkan nilai guru pada siklus 1 di atas, kriteria keberhasilan belum tercapai, karena semua guru belum mencapai KKM, sehingga perlu dilanjutkan dengan siklus berikutnya yaitu siklus II.

\section{5) Refleksi}

Dalam pembelajaran pada siklus 1 ini, tahap refleksi dilakukan oleh penulis dan guru kolaborator untuk mengevaluasi hasil observasi partisipasi aktif guru dan hasil dari pelaksanaan post test sebagai umpan balik setelah pembelajaran. Penggunaan metode "Berdikari”. meskipun belum maksimal, sebenarnya sudah menunjukkan partisipasi aktif guru. Masih banyak guru yang cenderung enggan untuk mengemukakan pendapat dan hal tersebut dikarenakan guru belum terbiasa mengikuti pembinaan dengan metode "Berdikari", sehingga masih banyak guru yang pasif dalam mengikuti pembelajaran.

Pada pelaksanaan pembelajaran menggunakan metode "Berdikari" untuk meningkatkan partisipasi aktif guru pada siklus 1 belum sepenuhnya terlaksana dengan baik. Hal ini terjadi, mungkin dikarenakan guru masih canggung dengan pembinaan metode "Berdikari".

Berdasarkan hasil refleksi tersebut, maka perlu adanya tindakan lanjutan untuk memperbaiki atau menyempurnakan pembinaan metode "Berdikari". Dikarenakan belum tercapainya target tindakan yang diinginkan pada pelaksanaan tindakan pada siklus 1, maka penulis dan guru sepakat untuk melanjutkan tindakan pada siklus II.

\section{b. Siklus II}

\section{1) Perencanaan Tindakan}

Perencanaan tindakan yang dilakukan pada siklus II adalah sebagai berikut:

a) Membuat agenda pembinaan metode "Berdikari" yang sesuai dengan materi yang akan diajarkan. 
b) Membuat Rencana Pelaksanaan pembinaan metode "Berdikari" tentang materi yang akan diajarkan. Rencana pembinaan ini disusun sebagai pedoman guru atau penulis dalam melaksanakan kegiatan pembelajaran di dalam Sekolah.

c) Menyusun dan mempersiapkan lembar observasi untuk mengetahui partisipasi guru selama proses pembinaan berlangsung. Lembar observasi ini digunakan sebagai pedoman penulis di dalam mengamati guru di Sekolah. Lembar ini akan diisi pada setiap pertemuan dan dibuat oleh penulis dengan dikonsultasikan pada guru dan dosen pembimbing.

d) Menyusun dan mempersiapkan soal-soal yang digunakan untuk mengukur kemampuan guru setelah proses pembinaan menggunakan metode "Berdikari” berlangsung post test).

e) Mempersiapkan alat dan media yang akan digunakan untuk proses pembelajaran di Sekolah.

\section{2) Pelaksanaan Tindakan}

\section{a) Pertemuan ke-1}

Langkah - langkah pelaksanaan tindakan pada siklus 1 pertemuan ke-1 adalah sebagai berikut:

(1) Kegiatan awal

(a) Penulis memberi motivasi terkait TUPOKSI

(b) Penulis mengecek administrasi yang sudah dibuat guru

(c) Penulis memberikan apersepsi yang berhubungan dengan materi yang akan disampaikan

(d) Penulis memberikan motivasi kepada guru dengan memberi pertanyaan kepada guru

(e) Penulis menyampaikan tujuan pembinaan dengan metode "Berdikari"

(2) Kegiatan inti

(3) Penutup

(a) Guru menyimpulkan materi yang telah disampaikan.

(b) Penulis memberikan tugas rumah

(d) Penulis menutup kegiatan pembinaan dengan berdo'a

(e) Penulis mngucapkan salam. 


\section{b) Pertemuan ke-2}

Langkah - langkah pelaksanaan tindakan pada siklus 1 pertemuan ke-2 adalah sebagai berikut:

(1) Kegiatan awal

(a) Penulis memberi motivasi terkait TUPOKSI

(b) Penulis mengecek administrasi yang sudah dibuat guru pada pertemuan pertama

(c) Penulis memberikan apersepsi yang berhubungan dengan materi yang akan disampaikan

(d) Penulis memberikan motivasi kepada guru dengan memberi pertanyaan kepada guru

(e) Penulis menyampaikan pentingnya melakukan diskusi sesama guru dan berinovasi.

(2) Kegiatan inti

(3) Penutup

(a) Guru menyimpulkan materi yang telah disampaikan.

(b) Penulis memberikan tugas rumah

(d) Penulis menutup kegiatan pembinaan dengan berdo'a

(e) Penulis mengucapkan salam.

\section{3) Pengamatan terhadap partisipasi aktif guru (observasi)}

Selama kegiatan pembelajaran berlangsung observer melakukan pengamatan secara langsung mengenai partisipasi yang ditunjukkan oleh guru dalam mengikuti pembinaan. Pada siklus II ini tingkat partisipasi aktif guru sudah mulai menunjukkan adanya peningkatan yang relatif stabil dan hampir semua guru sudah memperhatikan, berpartisipasi dan mengikuti proses pembelajan. Semua ini dapat dilihat dengan adanya peningkatan dari hampir semua aspek yang diamati. Hasil dari pengamatan guru pada siklus II, dapat dilihat pada tabel berikut ini:

Dari tabel dapat diketahui bahwa guru yang mendengarkan penjelasan sebanyak $86 \%$, mencatat penjelasan $100 \%$, memperhatikan pembelajaran $86 \%$, bertanya $86 \%$, menjawab pertanyaan $86 \%$, mengeluarkan pendapat $72 \%$, menghargai pendapat teman $86 \%$, mampu menjelaskan kembali $72 \%$. 


\section{4) Hasil Tes}

Hasil tes diperoleh data berupa angka-angka mengenai jumlah nilai yang diperoleh masing-masing guru terhadap soal yang dikerjakan setelah menerapkan metode "Berdikari" pada pembinaan peningkatan kemampuan guru mengajar.

Data yang diperoleh melalui tes dihitung masing-masing guru dengan cara mengakumulasikan nilai pada setiap item soal yang dijawab guru. Adapun hasil perhitungannya sebagai berikut:

Dalam menghitung nilai rata-rata guru secara keseluruhan digunakan rumus yang dikembangkan oleh Suharsimi Arikunto dalam bukunya Dasar-dasar evaluasi Pendidikan (2009: 264):

$$
\mathrm{X}=\frac{\sum}{\mathrm{N}}
$$

Berdasarkan rata-rata hasil belajar antara tes pada siklus I dan siklus II yang diketahui bahwa pada tes II $(78,5)$ mempunyai rata-rata lebih tinggi dibandingkan dengan rata-rata pada tes yang dilakukan di siklus I (50). Hal ini menunjukkan adanya peningkatan pada hasil belajar pada siklus II dalam pembinaan dengan metode "Berdikari”. Berdasarkan rata-rata pada siklus II di atas, kriteria keberhasilan sudah tercapai karena lebih dari $72 \%$ guru telah mencapai nilai yang tinggi, hal ini menunjukkan adanya pencapaian tingkat keberhasilan sesuai dengan kriteria keberhasilan yang telah ditetapkan.

\section{5) Refleksi}

Pada tahap refleksi penulis bersama guru mengevaluasi hasil dari tes dan observasi, dari hasil pengamatan dan refleksi di siklus II maka penerapan pembinaan dengan metode "Berdikari" dapat meningkatkan partisipasi aktif dan kemampuan belajar guru. Pada hasil partisipasi aktif guru, guru telah berpartisipasi secara aktif dalam pembelajaran dan keaktifan guru pada proses pembelajaran berlangsung dapat dilihat pada dokumentasi berupa foto-foto yang telah terlampir dalam lampiran, sedangkan pada hasil belajar semua guru sudah mencapai ketuntasan yang telah ditetapkan yaitu memperoleh nilai $\geq 75$ untuk masing-masing guru pada siklus ke II yaitu mencapai rata-rata 78,5. Jadi dari hasil pengamatan dan refleksi di siklus II penggunaan metode "Berdikari" dapat meningkatkan partisipasi aktif dan kemampuan belajar guru. Hal ini dikarenakan 
dengan menggunakan metode "Berdikari", guru lebih tertarik dan mempunyai motivasi yang tinggi untuk belajar. Keunggulan yang ada perlu dipertahankan untuk mendukung peningkatan dalam penggunaan media pembelajaran selanjutnya. Sedangkan beberapa kelemahan dalam media pembelajaran audio visual perlu diperbaiki untuk pertemuan selanjutnya. Berdasarkan hasil tes dan hasil observasi dari siklus II yang telah terjadi peningkatan dari siklus I, penulis dan guru sepakat bahwa pembinaan ini tidak dilanjutkan ke siklus III.

\section{B. Pembahasan}

Dalam penulisan ini, pembahasan lebih difokuskan pada; pelaksanaan penulisan tindakan Sekolah menggunakan metode "Berdikari", peningkatan partisipasi aktif pada guru, dan peningkatan kemampuan belajarnya.

\section{Pelaksanaan Penulisan Tindakan Sekolah Menggunakan Pembinaan dengan Metode "Berdikari".}

Pelaksanaan metode "Berdikari" untuk meningkatkan partisipasi aktif dan kemampuan mengajar guru dilakukan dalam dua siklus dan dilaksanakan dalam empat pertemuan di Sekolah. Penerapan metode "Berdikari” pada siklus I dilakukan dalam dua kali pertemuan, tetapi di dalam pelaksanaannya belum tercipta peningkatan partisipasi aktif dan kemampuan belajar guru secara maksimal, maka penulis sepakat untuk melanjutkan pada siklus berikutnya yaitu siklus II. Siklus demi siklus terbentuk untuk memberikan perbaikan dan perbandingan di dalam pembelajaran agar partisipasi aktif dan kemampuan belajar lebih meningkat sesuai dengan apa yang diharapkan penulis.

Dari pernyataan tersebut dapat disimpulkan bahwa dengan menggunakan metode "Berdikari" ini dapat memberi kemudahan bagi guru dalam meningkatkan kemampuan mengajarnya. Dalam pembelajaran siklus I masih ada guru yang kurang dapat memahami tupoksi, permasalahan yang diberikan oleh guru serta belum semua guru menunjukkan partisipasi aktif selama proses pembelajaran dengan menggunakan metode "Berdikari" ini. Akan tetapi setelah siklus II para guru berangsur-angsur dapat memahami tupoksi, serta hampir semua guru berpartisipasi aktif selama proses pembelajaran dengan menggunakan metode "Berdikari".

\section{Pembahasan Partisipasi Aktif Guru}

Hasil penulisan tindakan siklus I dan II dengan penggunaan metode "Berdikari" menunjukkan adanya peningkatan terhadap aktivitas belajar guru. Peningkatan terjadi 
pada observasi siklus II di mana dalam observasi ini yang diamati adalah partisipasi aktif guru.

Berdasarkan hasil observasi yang dilihat adanya peningkatan frekuensi dari siklus I sampai ke siklus II. Setiap indikator masing-masing siklus juga mengalami peningkatan. Pada siklus I dan siklus II peningkatan partisipasi guru yang paling tinggi adalah mencatat penjelasan, karena terjadi peningkatan sebesar $17 \%$ dan peningkatan partisipasi aktif guru yang paling rendah adalah indikator bertanya, karena hanya terjadi peningkatan sebesar $42 \%$.

Jadi kesimpulannya bahwa pembinaan dengan metode "Berdikari" dapat meningkatkan partisipasi aktif dan keterampilan guru dalam proses pembelajaran.

\section{Pembahasan Kemampuan Belajar Guru}

Penilaian yang digunakan pada setiap siklus adalah dengan menggunakan tes dan dilaksanakan pada setiap akhir siklus dengan soal-soal yang sesuai dengan materi yang diberikan kepada guru. Hal ini dilakukan untuk mengukur sejauh mana guru dapat menguasai materi yang telah disampaikan menggunakan metode "Berdikari". Hasil penulisan tindakan siklus I dan II dengan penggunaan metode "Berdikari" menunjukkan adanya peningkatan terhadap kemampuan mengajar guru.

Dari pernyataan tersebut, dapat disimpulkan bahwa dengan menggunakan metode "Berdikari" dapat meningkatkan kemampuan mengajar guru.

Setelah dilakukan penulisan yang dimulai dari siklus I, sampai pada siklus II dapat dilihat adanya peningkatan partisipasi aktif dan kemampuan mengajar guru dengan pembinaan menggunakan metode "Berdikari". Berdasarkan pemaparan kemampuan belajar di atas dapat diberikan penjelasan bahwa telah terjadi peningkatan kemampuan belajar guru dari siklus I mencapai rata-rata 50\% naik menjadi rata-rata 78,5\% pada tahap siklus II. Dari rata-rata tersebut dapat diketahui peningkatan rata-rata 28,5\% dari siklus I ke siklus II. Dapat disimpulkan bahwa pembinaan dengan metode "Berdikari” dapat meningkatkan kemampuan mengajar guru.

\section{SIMPULAN}

Berdasarkan hasil analisis data dan pembahasan yang telah penulis lakukan terhadap aktivitas mengajar guru di SDLBN Kalirejo dapat ditarik kesimpulan sebagai berikut:

1. Penerapan pembinaan dengan metode "Berdikari" dapat meningkatkan kemampuan guru mengajar dilihat dari adanya peningkatan persentase. 
2. Peningkatannya dapat dilihat dari hasil observasi pada siklus I dan siklus II. Pada Aspek mendengarkan penjelasan siklus I sebesar $70 \%$ dan siklus II sebesar $86 \%$. Aspek mencatat penjelasan siklus 1 sebesar 56\% dan siklus II sebesar 100\%. Aspek memperhatikan pembelajaran siklus I sebesar 54\%.dan siklus II sebesar 86\%. Aspek bertanya siklus I sebesar $28 \%$ dan pada siklus II sebesar $86 \%$. Aspek menjawab pertanyaan siklus I sebesar $28 \%$ dan siklus II sebesar $86 \%$. Aspek mengeluarkan pendapat siklus I sebesar $28 \%$ dan pada siklus II sebesar 72\%. Aspek menghargai pendapat teman siklus I sebesar $84 \%$ dan pada siklus II sebesar $86 \%$. Aspek mampu menjelaskan kembali siklus I sebesar $45 \%$ dan pada siklus II sebesar $72 \%$. Hal ini menunjukkan bahwa terjadi peningkatan terhadap partisipasi aktif guru dalam pembinaan "Berdikari”.

3. Pembinaan guru dengan metode "Berdikari" juga dapat meningkatkan kemampuan guru dalam memahami pengetahuan pembelajaran. Peningkatan hasil belajar ini dapat dilihat dari adanya perubahan nilai rata-rata yang diperoleh guru pada setiap akhir siklus. Nilai rata-rata yang diperoleh guru pada siklus I sebesar 50 dan siklus II sebesar 78,5, ini membuktikan bahwa metode "Berdikari" dapat meningkatkan kemampuan belajar guru.

\section{SARAN}

1. Bagi Sekolah

Sekolah dapat :

a. Menggunakan metode pembinaan "Berdikari" secara terstruktur.

b. Mengembangkan metode pembinaan "Berdikari” sesuai kondisi sekolah.

2. Bagi Guru

c. Guru perlu meningkatkan pengetahuan pembelajaran dengan metode "Berdikari".

d. Guru harus selalu melakukan "Berdikari" yaitu berlatih, berdiskusi, dan berkarya inovasi.

e. Termotivasi untuk mengembangkan kompetensi dirinya.

3. Bagi Penulis Selanjutnya

a. Dapat melakukan penulisan lebih mendalam tentang metode atau strategi untuk meningkatkan kompetensi guru.

b. Menjadikan metode "Berdikari" sebagai referensi untuk mengembangkan penulisan sejenis. 


\section{DAFTAR PUSTAKA}

Emsir. (2010). Metodologi Penulisan Kualitatif Analisis Data. Jakarta: PT. Rajagrafindo Persada.

Mulyasa.(2004). Menjadi Guru professional. Bandung: PT. Remaja Rosdakarya.

Nana Sudjana.(2006). Penilaian Hasil Proses Belajar Mengajar. Bandung: PT. Remaja Rosdakarya.

Riduwan.(2009). Skala Pengukuran Variabel-Variabel Penulisan. Bandung: Alfabeta.

Rochiati Wiriaatmadja. (2009). Metode Penulisan Tindakan Sekolah. Bandung: PT. Remaja Rosdakarya.

Slameto.(2010). Belajar dan Faktor-Faktor yang Mempengaruhi. Jakarta: Rineka Cipta.

Sugihartono.(2007). Psikologi Pendidikan. Yogyakarta: UNY .Press.

Sugiyono. (2008). Metode Penulisan Kuantitatif, Kualitatif dan $R \& D$. Bandung: CV. Alfabetta.

Suharsimi Arikunto. (2002) Prosedur Penelitian Suatu Pendekatan . Jakarta: PT. Rineka Cipta

Suharsimi Arikunto. (2009). Dasar-dasar Evaluasi Pendidikan (Edisi Revisi, cetakan 7). Jakarta: Bumi Aksara

Suharsimi Arikunto, dkk. (2015). Penulisan Tindakan Sekolah.Jakarta : Bumi Aksara.

Sumadi Suryabrata. (2006). Psikologi Pendidikan. Jakarta: PT. Raja Grafindo Persada.

Suryobroto. (1997). Proses Belajar Mengajar di Sekolah. Jakarta: PT. Rineka Cipta.

Susilo. (2007). Panduan Penulisan Tindakan Sekolah. Yogyakarta: Pustaka Book Publisher. 